\title{
NEED ASSESSMENT MASYARAKAT SEKITAR KAMPUS DI JATINANGOR
}

\author{
Oleh : \\ Nandang Mulyana
}

\begin{abstract}
ABSTRAK
Keberadaan perguruan tinggi di Jatinangor sesuai dengan SK Gubernur Nomor 593/3590/1987 yang menjadikan Wilayah Jatinangor sebagai kawasan pendidikan. Dengan dijadikannya kawasan pendidikan, perguruan tinggi yang berdiri di Jatinangor diharapkan untuk dapat membantu perkembangan masyarakat kearah yang lebih baik. Hal ini sesuai dengan Tri Darma Perguruan Tinggi yang salah satu butirnya adalah pengabdian kepada masyarakat. Pelaksanaan pengabdian kepada masyarakat diimplementasikan dalam berbagai program yang direncanakan sesusia dengan kebutuhan dan potensi yang dimiliki oleh masyarakat yang bersangkutan.

Lokasi penelitian untuk melihat kebutuhan dan potensi serta program yang telah di lakukan oleh perguruan tinggi ini di tiga desa. Ketiga desa tersebut adalah Desa Hegarmanah, Sayang, dan Cilayung. Pemilihan ketiga desa ini karena ketiga desa tersebut dekat dengan lokasi berdirinya perguruan tinggi dan memiliki karakteristik yang berbeda. Metode penelitian yang digunakan adalah survey dengan mengambil sampel penelitian secara acak.

Hasil penelitian menitikberatkan pada kebutuhan aspek pendidikan, kesehatan, dan ekonomi. Selama ini kebutuhan dari masyarakat ketiga desa tersebut dari aspek pendidikan hampir sama yaitu masih sedikitnya putra-putra yang berasal dari ketiga desa tersebut yang dapat diterima perguruan tinggi yang ada di Jatinangor. Kebutuhan dari aspek kesehatan adalah masih kurangnya sarana pelayanan kesehatan bagi Desa Cilayung, dan masih dirasakan mahal biaya untuk pelayanan kesehatan. Sedangkan aspek ekonomi lebih kepada masih banyaknya tenaga kerja setempat yang belum tertampung dunia usaha disana.

Ditinjua dari sisi potensi, ketiga desa yang dijadikan lokasi penelitian mempunyai potensi yang berbeda-beda. Desa Hegaramanah mempunyai potensi untuk mengembangkan usaha jasa, sedangkan Desa Sayang masih merupakan desa peralihan yang dapat dikembangkan menjadi desa yang lebih maju lagi. Desa Cilayung mempunyai potensi pengembangan petanian dan kerajinan.

Program pengabdian kepada masyarakat juga dirasakan belum merata. Hal ini dapat dilihat bahwa kegiatan yang dilakukan oleh perguruan tinggi yang ada di Jatinangor lebih banyak dilakukan di Desa Hegarmanah dan Desa Sayang. Sedangkan Desa Cilayung sangat jarang. Hal ini disebabka karena untuk mencapai Desa Cilayung cukup jauh padahal secara geografis letaknya sangat dekat desa Univarsitas Padjadjaran.
\end{abstract}

Kata kunci : perubahan social, kebutuhan, potensi, program

\section{ABSTRACT}

Jatinangor was defined as Education Zone based on Government Letter No. 593/3590/1987. This policy demands all schools in Jatinangor to participate in community services, which is part of The Three Basics Principle of Schools. It is implemented in various programs that present community's needs and abilities. 
This research was conducted in three villages, Hegarmanah, Sayang, and Cilayung. All the villages were located around the school in Jatinangor and have different characteristics. The research method was survey with random sampling.

The result in this research is concerning to the needs in education, health, and economic. In education aspect, all three villages have the same condition that is only a few students came from those villages. In health aspect, community health services and medical costs were became the potential problems in Cilayung. In economic aspect, the employment issues still became the major problem.

The three villages have different abilities. Hegarmanah was potential to develop the private sector; Sayang was potential to be more developed village; and Cilayung has abilities in agriculture and handy craft sector.

Community services programs were not distributed well. There were many programs that implemented in Hegarmanah and Sayang, but not in Cilayung. It caused by the access to Cilayung. Keywords : Social Change, need, potent, programe

\section{PENDAHULUAN}

Ditetapkannya Wilayah Jatinangor sebagai Kawasan Pendidikan berdasarkan SK Gubernur Nomor 593/3590/1987 membawa dampak yang sangat besar bagi perkembangan Jatinangor. Perubahan yang sangat besar dirasakan oleh masyarakat sekitar Jatinangor. Perubahan yang terjadi akibat keberadaan perguruan tinggi di Jatinangor adalah semakin banyaknya kaum pendatang baik itu mahasiswa yang kuliah di Jatinangor maupun para pendatang yang berusaha untuk memanfaatkan peluang usaha. Banyak peluang usaha yang dapat dimanfaatkan dengan kehadiran perguruan tinggi dan mahasiswa di Jatinangor. Usaha pemondokan dan usaha yang menunjang kelancaran kuliah sebagai contoh.

Selain keterbukaan peluang usaha, kehadiran perguruan tinggi dan mahasiswa di Jatinangor juga menyebabkan semakin banyaknya lahan yang beralih fungsi khususnya untuk usaha. Dengan beralihfungsinya lahan yang dahulu dijadikan lahan pertanian menyebabkan masyarakat pribumi yang asalnya mempunyai pekerjaan sebagai petani beralih mencari pekerjaan lain. Dengan kondisi ini menyebabkan kebutuhan dan potensi yang ada dalam masyarakat juga berubah. Oleh sebab itu penelitian ini diarahkan untuk menemukan kebutuhan dan potensi apa yang sebenarnya ada dalam masyarakat sekitar kampus di Jatinangor setelah sekian lama berdiri perguruan tinggi, serta mengetahui programprogram yang telah diberikan oleh perguruan tinggi dan tanggapan dari masyarakat mengenai keberadaan perguruan tinggi di Jatinangor.

\section{IDENTIFIKASI MASALAH}

1. Apakah kebutuhan-kebutuhan dari masyarakat sekitar kampus di Jatinangor?

2. Bagaimana potensi-potensi yang ada dalam masyarakat sekitar kampus di Jatinangor?

3. Apakah program-program yang telah diterima oleh masyarakat sekitar dari perguruan tinggi yang ada di Jatinangor?

4. Bagaimana tanggapan masyarakat terhadap keberadaan perguruan tinggi di Jatinangor?

\section{TUJUAN DAN KONTRIBUSI PENELITIAN}

Adapun tujuan dari penelitian ini adalah untuk memperoleh dan mengkaji :

1. Kebutuhan-kebutuhan yang ada dalam masyarakat sekitar kampus di Jatinangor.

2. Potensi-potensi yang dimiliki oleh masyarakat di sekitar kampus di Jatinangor.

3. Program-program yang telah dilakukan oleh perguruan tinggi yang ada di Jatinangor terhadap masyarakat sekitar

4. Tanggapan masyarakat terhadap keberadaan perguruan tinggi di Jatinangor

Sedangkan kontribusi dari penelitian ini diharapkan menjadi bahan masukkan bagi para penyusun dan pelaksanan kebijakan yang terkait dengan upaya-upaya pembangunan termasuk didalamnya perguruan tinggi. Selain 
itu penelitian ini juga diharapkan menjadi masukan terhadap perguruan tinggi yang ada di Jatinangor mengenai harapan-harapan dari masyarakat terhadap keberadaan perguruan tinggi yang ada di Jatinangor.

\section{TINJAUAN PUSTAKA}

Perubahan status Jatinangor dari daerah pertanian menjadi kawasan pendidikan membawa konsekuensi bagi masyarakat. Kedatangan ribuan mahasiswa dengan berbagai atribut budaya mempengaruhi kehidupan masyarakat. Demikian juga dengan penyediaan lahan dalam memenuhi bagi kebutuhan penginapan mahasiswa, menjadikan terjadinya perubahan fungsi lahan. Lahan yang asalnya lahan pertanian berubah menjadi perumahan untuk menampung penginapan mahasiswa serta menjadi sarana dan prasarana pendukung lainnya. Perubahan fungsi lahan ini mendorong masyarakat untuk berubah baik itu mata pencaharian maupun nilai-nilai yang melekat pada masyarakat agraris. Secara sosiologis masyarakat telah mengalami perubahan sosial.

Perubahan sosial diartikan sebagai proses dimana dalam suatu sistem sosial terdapat perbedaan-perbedaan yang dapat diukur yang terjadi dalam kurun waktu tertentu (Lawang, 1998). Definisi Lawang ini melihat bahwa ada perbandingan mengenai data dari suatu sistem sosial yang mengalami perubahan sosial. Selanjutnya Lauer mendefinisikan perubahan sosial sebagai perubahan yang terjadi di setiap tingkat kehidupan. Definisi dari Lauer ini memperlihatkan bahwa perubahan sosial ini dapat terjadi pada semua level atau aspek kehidupan. Kemudian Farley memberi arti pada perubahan sosial sebagai perubahan pola perilaku, hubungan sosial, lembaga, dan struktur sosial pada waktu tertentu. Berdasarkan definisi-definisi yang diberikan oleh para ahli tersebut terlihat bahwa perubahan sosial mempunyai empat syaratsyarat. Syarat-syarat tersebut dapat digunakan untuk melihat bahwa suatu masyarakat mengalami perubahan sosial. Syarat-syarat tersebut adalah :

1. Dimensi waktu. Untuk melihat suatu perubahan sosial yang terjadi dalam masyarakat, harus dibandingkan dua atau lebih waktu sesuai dengan perjalanan masyarakat yang akan dilihat perubahannya tersebut. waktu yang akan dibandingkan disesuaika dengan kebutuhan.

2. Adanya perbedaan. Dengan membandingkan suatu masyarakat pada waktu yang berbeda akan terlihat perbedaan pada masyarakat yang bersangkutan.

3. Adanya sistem sosial. Sistem sosial disini dapat berupa masyarakat. Perubahan sosial tentunya akan melihat perubahan yang terjadi dalam suatu masyarakat.

4. Adanya pengaruh terhadap sistem sosial. Suatu masyarakat dikatakan berubah jika perubahan yang terjadi membawa pengaruh terhadap masyarakat yang bersangkutan. Pengaruh ini meliputi berbagai aspek dalam kehidupan masyarakat.

Perubahan social yang terjadi sangat bersifat luas dan mencakup berbagai aspek kehidupan. Akibatnya untuk menganalisisnya juga tergantung kepada unit analisis yang digunakan sesuai dengan level mana perubahan social terjadi. Akan tetapi jika dilihat dari tipe perubahan yang terjadi maka dapat dilihat pada tabel berikut : 


\section{Tabel 1}

Tipe-tipe Perubahan Sosial

\begin{tabular}{|c|c|c|c|}
\hline \multirow{2}{*}{$\begin{array}{l}\text { Dimensi } \\
\text { Waktu }\end{array}$} & \multicolumn{3}{|c|}{ Level Masyarakat } \\
\hline & Mikro (Individu) & $\begin{array}{l}\text { Menengah } \\
\text { (Kelompok) }\end{array}$ & Makro (Masyarakat) \\
\hline $\begin{array}{l}\text { Jangka } \\
\text { Pendek }\end{array}$ & $\begin{array}{c}\text { Tipe } 1 \\
\text {-Perubahan sikap } \\
\text {-Perubahan } \\
\text { perilaku }\end{array}$ & $\begin{array}{c}\text { Tipe } 3 \\
\text {-Perubahan } \\
\text { normatif } \\
\text {-perubahan } \\
\text { administrasi }\end{array}$ & $\begin{array}{c}\text { Tipe } 5 \\
\text {-Invensi-inovasi } \\
\text {-Revolusi }\end{array}$ \\
\hline $\begin{array}{l}\text { Jangka } \\
\text { Panjang }\end{array}$ & $\begin{array}{c}\text { Tipe } 2 \\
\text { Perubahan siklus } \\
\text { kehidupan }\end{array}$ & $\begin{array}{c}\text { Tipe } 4 \\
\text { Perubahan } \\
\text { organisasional } \\
\end{array}$ & $\begin{array}{c}\text { Tipe } 6 \\
\text { Evolusi sosio-kultural }\end{array}$ \\
\hline
\end{tabular}

Sumber : Zaltman, Kotler, Kaufman, 1972; 3

Berdasarkan tabel tersebut terlihat bahwa perubahan social mempunyai berbagai macam tipe yang diseuaikan dengan jangka waktu terjadinya perubahan dan level masyarakat yang terkena perubahan social. Berdasarkan Zaltman, Kotler, dan Kaufman perubahan social itu mempunyai enam tipe. Tipe perubahan social tersebut jika diamati secara saksama memperlihatkan bahwa semakin lama waktu yang dibutuhkan untuk terjadinya perubahan social dan level masyarakat yang semakin luas maka semakin luas juga jangkauan perubahan social tersebut.

Demikian juga perubahan yang terjadi di Jatinangor setelah keberadaan perguruan tinggi menyentuh semua tingkatan masyarakat baik itu invididu maupun masyarakat secara keseluruhan. Kehadiran mahasiswa dan perubahan fungsi lahan juga mendorong terjadinya perubahan social baik berupa tipe 1 ( perubahan pada individu) bahwa sampai pada tipe 6 (perubahan pada masyarakat dan kebudayaannya). Dengan demikian dalam masyarakat akan muncul kebutuhan dan potensi baru yang berbeda dengan kebutuhan dan potensi sebelumnya, sehingga diperlukan adanya need assessment baru untuk mengetahui kebutuhan dan potensi yang baru.

\section{METODE PENELITIAN}

Jenis metode penelitian yang digunakan dalam penelitian ini adalah metode deskriptif, dan menggunakan pendekatan kuantitatif, yaitu kegiatan penelitian yang berguna untuk memahami kebutuhan dan potensi yang dimiliki oleh masyarakat sekitar kampus di Jatinangor. Sedangkan teknik penelitian yang digunakan adalah dengan menggunakan teknik penelitian survey yaitu kegiatan penelitian yang mengambil sampel dari satu populasi dan menggunakan kuesioner atau angket sebagai alat pengumpulan data yang utama (Singarimbun dan Effendi, 1989:3-5).

Sumber data yang digunakan dalam penelitian ini adalah data primer dan data sekunder. Pelaksanaan pengumpulan data primer dapat dilakukan setelah populasi dan sampel dapat dipetakan, dari beberapa teknik probability sampling yang ada, penelitian ini menggunakan teknik proportionate random sampling 


\section{HASIL PENELITIAN DAN PEMBAHASAN}

Responden yang dijadikan sumber data pada penelitian ini adalah anggota masyarakat yang sudah lama tinggal di lokasi penelitian. Hal ini dimaksudkan agar semua perkembangan mengenai perubahan dari kebutuhan dan potensi serta program yang telah diberikan oleh perguruan tinggi dapat diberikan oleh responden. Berdasarkan lamanya tinggal ini responden pada umumnya tinggal dilokasi penelitian pada umumnya lebih dari 6 tahun. Bahkan responden yang berasal dari Desa Sayang dan Desa Cilayung ada responden yang tinggal lebih dari 15 tahun. Responden yang telah tinggal lebih dari 15 tahun adalah anggota masyarakat pribumi yang sejak lahir sudah tinggal di desa tersebut.

Kebutuhan masyarakat di ketiga desa yang dijadikan lokasi penelitian meliputi aspek pendidikan, kesehatan, dan ekonomi. Ditinjau dari aspek pendidikan terjadi perbedaan kebutuhan antara desa yang dijadikan lokasi penelitian. Desa Hegarmanah yang merupakan desa termaju tidak terlalu mempunyai masalah dengan sarana dan tenaga pendidikan. Hal ini disebabkan karena di Desa Hegarmanah sudah tersedia pada semua jenjang baik sekolah dasar, menengah bahkan perguruan tinggi. Kebutuhan dan masalah yang dihadapi oleh responden dari Desa Hegarmanah adalah masih sulitnya masyarakat setempat untuk melanjutkan pendidikan tinggi yang ada di Jatinangor. Kesulitannya adalah ketiadaan biaya karena biaya untuk melanjutkan pendidikan ke perguruan tinggi dirasakan mahal. Selain itu juga karena kemampuan secara intelektual anggota masyarakat setempat dirasakan masih ada di bawah para pendatang.

Responden dari Desa Sayangpun merasakan hal sama tetapi masalahnya bukan hanya untuk jenjang pendidikan tinggi, tetapi kebutuhan anggota masyarakat akan pendidikan di Desa Sayang sejak dari sekolah menengah atas. Di Desa Sayang tidak ada sekolah menengah atas, sehingga kalau meu meneruskan pendidikan ke tingkat menengah atas harus keluar desa. Akibatnya pengeluaran untuk melanjutkan pendidikan sekolah menengah menjadi lebih besar karena perlu untuk ongkos.

Sedangkan responden yang berasal dari Desa Cilayung lebih membutuhkan lagi sarana pendidikan dasar. Di Desa Cilayung hanya ada sekolah dasar, sedangkan jenjang pendidikan lain tidak tersedia. Jadi untuk pendidikan dasar Sembilan tahunpun masih sulit untuk Desa Cilayung. Dengan demikian masyarakat Desa Cilayung sangat membutuhkan sarana pendidikan dasar khususnya sekolah menengah pertama. Sebab dengan tidak adanya sarana sekolah tersebut anak-anak harus sekolah ke luar desa sehingga memerlukan biaya yang cukup besar apalagi jika anak-anak melanjutkan pendidikan yang lebih tinggi lagi.

Dilihat dari aspek kesehatanpun memperlihatkan hal tidak berbeda. Responden yang berasal dari Desa Hegarmanah menyatakan bahwa sarana kesehatan yang ada di desanya dirasakan sudah cukup kecuali untuk rumah sakit. Sarana kesehatan di Desa Hegarmanah ini sudah cukup baik, bahkan puskesmas yang ada di Desa Hegarmanah sudah ada pelayanan rawat inap. Kebutuhan dan permasalahan yang dihadapi oleh responden dan anggota masyarakat di Desa Hegarmanah lebih kepada masih mahalnya biaya untuk mendapatkan pelayanan kesehatan khususnya pelayanan kesehatan yang dikelola oleh swasta seperti praktik dokter.

Responden yang berasal dari Desa Sayang menyatakan bahwa sarana kesehatan yang ada di desanya sudah cukup lengkap. Hanya saja dalam kenyataannya sarana 
kesehatan yang ada di Desa Sayang masih belum lengkap dalam pelayanannya. Puskesmas yang ada di Desa Sayang hanya memberikan pelayanan rawat jalan, sedangkan jika ada anggota masyarakat Desa Sayang yang memerlukan rawat inap harus pergi keluar desa sehingga memerlukan ongkos untuk transportasi yang lebih tinggi. Selain itu responden juga menyatakan bahwa biaya untuk memperoleh pelayanan kesehatan dirasakan masih tinggi.

Responden dari Desa Cilayung menyatakan bahwa sarana dan pelayanan yang ada di desanya masih sangat kurang. Hal ini diperlihatkan oleh responden bahwa di Desa Cilayung hanya ada toko obat saja, sedangkan pelayanan lain tidak ada. Anggota masyarakat yang sakit harus dibawa keluar desa dengan biaya yang lebih besar. Demikian sarana kesehatan yaitu toko obat yang ada di Desa Cilayung juga tidak lengkap persediaan obatobatannya. Jadi kalau memerlukan obat dan tidak tersedia di toko obat tersebut harus mencari keluar desa yang tentunya memerlukan biaya yang besar untuk transportasi.

Sedangkan kebutuhan dari aspek ekonomi lebih banyak berhubungan dengan pekerjaan yang dilakukan. Kurangnya modal dan ketrampilan menjadi permasalahan yang paling banyak dihadapi oleh responden disamping pengangguran yang merata dirasakan oleh semua responden dari ketiga desa. Hanya saja responden dari Desa Cilayung tidak mempunyai permasalahan dengan rendahnya ketrampilan. Mereka berangapan bahwa masyarakat Desa Cilayung mempunyai ketrampilan dalam hal membuat kerajinan tangan sehingga tidak memerlukan ketrampilan yang lain. Hanya saja yang menjadi permasalahan adalah pemasaran yang tidak lancar sehingga pada akhirnya kalah bersaing dengan produk serupa dari desa atau kota lain.

Potensi yang dimiliki oleh ketiga desa yang menjadi lokasi penelitan adalah letak geografis yang dekat dengan jalan yang menghubungkan kota-kota Bandung dengan Sumedang dan Cirebon. Letak geografis ini menjadi potensi yang menyebabkan akses masyarakat dari ketiga desa mudah. Masyarakat jika akan memasarkan ataupun membuka usaha lain sangat mudah dengan akses seperti ini karena selain mudah transportasi juga banyaknya orang luar yang datang khususnya keluarga mahasiswa. Potensi yang lain khususnya respoden yang berasal dari Desa Sayang dan Desa Cilayung adalah masih kuatnya masyarakat memegang adat yang talah ada dan diturunkan kepada mereka. Keteguhan ini menjadi potensi karena perubahan social di Jatinangor sangat cepat dan cenderung pada beberapa hal negatif. Lebih khusus lagi bagi masyarakat di Desa Cilayung mempunyai potensi dalam bidang pembuatan kerajinan. Dengan modal ini masyarakat tida perlu lagi untuk mencari perkerjaan yang lain yang tidak sesuai dengan keahliannya.

Program-program yang pernah diberikan kepada masyarakat oleh perguruan tinggi yang ada di Jatinangor dirasakan oleh semua responden tidak merata. Hal ini dapat dilihat dari tabel sebagai berikut : 
Tabel 2

Program yang Diberikan oleh Perguruan Tinggi

\begin{tabular}{|l|c|c|c|}
\hline \multicolumn{1}{|c|}{ Desa } & Hegarmanah & Sayang & Cilayung \\
Program & & 5 & 1 \\
\hline Penyuluhan dan Pengobatan gratis & 9 & 5 & 1 \\
\hline Penyuluhan pertanian & 0 & 4 & 0 \\
\hline Praktikum mahasiswa & 12 & 2 & 0 \\
\hline Pemeriksaan gigi & 6 & 2 & 0 \\
\hline Pelatihan wirausaha & 6 & &
\end{tabular}

Sumber : Hasil Penelitian 2015

Program yang diberikan oleh perguruan tinggi yang ada di Jatinangor lebih banyak diberikan kepada masyarakat yang ada di Desa Hegramanah. Hal ini disebabkan karena Desa Hegarmanah terletak sangat dekat dengan perguruan tinggi yang ada di Jatinangor. Sedangkan program di desa lain tidak sebanyak program di Desa Hegarmanah. Bahkan untuk Desa Cilayung responden menyatakan hanya ada satu kali program yaitu penyuluhan pertanian dan pengobatan gratis. Selain itu tidak pernah lagi ada program dari perguruan tinggi bagi masyarakat di Desa Cilayung.

Keberadaan perguruan tinggi di Jatinangor mendapat tanggapan dari responden baik tanggapan yang bersifat positif maupun tanggapan negatif. Tanggapan yang bersifat positif diberikan oleh responden yaitu dengan adanya perguruan tinggi di Jatinangor ada dua hal positif yang dirasakan pertama, membuka peluang usaha sehingga banyak tenaga kerja setempat yang terserap baik itu membuka usaha sendiri maupun bekerja pada pengusaha lain. Kedua memunculkan motivasi bagi anakanak responden untuk melanjutkan pendidikan pada jenajng tertinggi, sehingga pada akhirnya nanti dapat membangun daerahnya.

Tanggapan negatif diberikan oleh responden menyangkut pertama semakin banyaknya lahan yang beralih fungsi sehingga banyak anggota masyarakat yang berganti pekerjaan. Pekerjaan yang sekarang dijalani lebih banyak pekerjaan kasar yang tidak memerlukan ketrampilan sehingga penghasilan yang didapatpun tidak banyak. Akibatnya penghidupan masyarakat setempat tetap saja tidak ada perubahan bahkan dirasakan semakin munurun karena mereka sekarang tidak mempunyai lahan pertanian lagi. Tanggapan negatif lainnya adalah dampak dari perilaku buruk mahasiswa. Mahasiswa sebagai apnutan bagi anak-anak setempat jika berperilaku buruk akan dijadikan bahan untuk ditiru. Dengan demikian banyak anak muda setempat yang berperilaku buruk seperti penggunaan narkoba dan sex bebas dilakukan.

\section{KESIMPULAN DAN SARAN}

\section{Kesimpulan}

Keberadaan perguruan tinggi di Jatinangor pada awalnya diharapkan dapat membawa perubahan bagi masyarakat sekitarnya. Hal ini disebabkan karena perguruan tinggi sebagai pusat ilmu pengetahuan dapat mempraktikkan ilmunya tersebut dalam masyarakat. Harapan ini sesuai dengan Tri Darma Perguruan tinggi yang salah satu pointnya adalah pengabdian kepada masyarakat. Program yang dibuat oleh perguruan tinggi tentunya harus didasarkan kepada kebutuhan dan potensi yang ada di 
dalam masyarakat. Kebutuhan dan potensi yang dimiliki oleh masyarakat di lokasi penelitian berbeda beda. Pengetahuan tentang kebutuhan dan potensi yang ada dapat digunakan baik itu oleh perguruan tinggi maupun pemerintah daerah untuk membuat program yang sesuai dengan kebutuhan dan potensi yang dimiliki oleh masyarakat.

\section{Saran}

Berdasarkan kesimpulan yang diambil maka saran yang diusulakn sebagai berikut:

a. Perguruan tinggi yang ada di Jatanangor dalam membuat program kegiatan disesuaikan dengan kebutuhan dan potensi yang dimiliki oleh masyarakat tempat rencana kegiatan tersebut akan dilakukan.

b. Perguruan tinggi dalam membuat program dapat bekerja sama dengan pemerintah daerah setempat sehingga program yang direncanakan sesuai dengan arah pembangunan dari pemerintah daerah dan dapat menghindari tumpang tindih kegiatan dan lebih menekan anggaran.

c. Buat rencana kegiatan dalam jangka panjang sehingga program tersebut lebih terasa manfaatnya dalam jangka panjang.

\section{DAFTAR PUSTAKA}

Abdul Syani, 1995, Sosiologi dan Perubahan Masyarakat, Dunia Pustaka Jaya

Arikunto, Suharsimi. 1988. Penilaian Program Pendidikan. Jakarta : Bina Aksara. \& Cepi Safrudin Abdul Jabar. 2008. Evaluasi Program Pendidikan. Jakarta : Bumi Aksara.

Friedlander, Walter. A, Introduction to Social Work, Third Edition

Horton, Paul dan Chester L. Hunt, 1990, Sosiologi jilid 1 dan 2 (terjemahan oleh Aminudin Ram dan Tita Sobari), Erlangga Jakarta

Isaac, Stephen \& William B. Michael. 1981. Handbook in Research and Evaluation. California. Edlts Publisher

Lauer, Robert H., 1993, Perspektif tentang Perubahan Sosial, Rineka Cipta, Jakarta

Soenato. 2005. Handout: Evaluasi Program Pendidikan. Pascasarjanan UNY

Stufflebeam, Daniel L. 1985. Conducting Educational Need Assessment. U. S.A : Kluwer Academic Publishers.

Soerjono Soekanto, 1986 Sosiologi Suatu Pengantar, Rajawali, Jakarta 